\title{
Special Issue on History and Philosophy of Mathematics in Mathematics Education
}

\author{
Victor J. Katz • Uffe Thomas Jankvist • Michael N. Fried • \\ Stuart Rowlands
}

Published online: 13 November 2013

(C) Springer Science+Business Media Dordrecht 2013

\section{Introduction and Motivation}

Although Science \& Education has published papers specifically concerning mathematics over the years-some quite significant for education-mathematics has never received the spotlight. Indeed, when the journal was established it bore the subtitle, Contributions from History, Philosophy and Sociology of Science and Mathematics, but so few papers on mathematics were received in those years that the word "mathematics" was duly dropped. Yet within the community of science and mathematics educators, there is no lack of interest at least in the contributions of history and philosophy of mathematics to mathematics education, particularly the history of mathematics. Besides publications such as those we have listed at the end of this introduction, one can point to the activities of the International Study Group on the Relations between the History and Pedagogy of Mathematics (HPM) which dates back to 1972, and which almost from the start became an affiliated study group of the International Commission on Mathematical Instruction (ICMI), the largest and oldest international organization for mathematics education. International conferences of HPM have been held in Europe, Canada, Australia, Taiwan, Mexico, and Korea in association with the quadrennial International Congress on Mathematical Education (ICME). The European Summer University on History and Epistemology in Mathematics Education (ESU), now held every 4 years as well, is another regular venue for meetings dealing with history in mathematics education, as is the working group on History in Mathematics Education at the biennial Congress of European

V. J. Katz $(\bowtie)$

University of the District of Columbia, Silver Spring, MD, USA

e-mail: vkatz@udc.edu

U. T. Jankvist

Aarhus University, Aarhus, Denmark

M. N. Fried

Ben Gurion University, Beersheba, Israel

S. Rowlands

University of Plymouth, Plymouth, UK 
Research in Mathematics Education (CERME). There are also other regular local and regional meetings, including the semi-annual meetings of the Americas section of HPM. Given this level of interest, restoring "mathematics" to the subtitle of Science \& Education, at least for one issue, seemed to us in order. Thus, this special issue.

Most of the papers presented here concern the history of mathematics in mathematics education, but the special issue was defined to include also the philosophy of mathematics. The use of philosophy of mathematics in the teaching and learning of mathematics has not received nearly as much attention in mathematics education as has the history of mathematics. There are signs that this situation may be changing, and these are welcome since, in our view, philosophy of mathematics has as much to offer the teaching and learning of mathematics as it does to understand the basic nature of mathematics. One might be tempted, therefore, to propose two special issues, one for history and one for philosophy, for these can be thought of as separate domains and usually are. But the truth is they are closely linked to one another, and, when taken together, they are able to bring out more general issues of history, philosophy, and culture, as is the sociology of science, which remains in Science \& Education's subtitle. For this reason, a focused treatment of history and philosophy of mathematics can also enlighten science educators as well as mathematics educators. Generally, we maintain that it is important for those involved in science education to understand how mathematics and its history relate to the teaching of science, and conversely how the teaching and learning of mathematics engage with science. Reflections concerning such interplays were part of the motivation of launching this special issue in the first place.

Still, history is our main focus. Like any subfield of mathematics and science education, history of mathematics in mathematics education has shifted emphases over the years and is even now in flux. When interest in the educational potential of history of mathematics reawakened in the 1970s (history of mathematics in mathematics education was not, needless to say, a discovery of the 1970s!) much of the literature simply advocated uncritically its incorporation into classroom teaching. It was typically a matter of teachers' or researchers' suggesting teaching ideas based on history and reporting on their own (usually positive) experiences of using history with students. There are still studies of this kind and still a place for them; one should not belittle them (see, for example, the papers by Taani and by Papadopoulos in this issue). Recent years, however, have seen more critical efforts, including an increasing number of carefully carried out empirical research studies.

In recent years too, we have also come to recognize in a pointed way the great difference it makes at both a practical and theoretical level whether history of mathematics is presented as a series of isolated examples, stories, and anecdotes garnered from secondary sources or whether it is presented as ideas contained in coherent mathematical texts. Hence, several new studies deal with the use of original sources in the teaching and learning of mathematics (see Barnett et al. in this issue). Again, these are not merely a matter of advocating the use of original or primary sources but also attempts to define why such sources are important and to confront the difficulties of working with the unfamiliar (where the difficulty is often seeing that they in truth are unfamiliar!). To this end, methodologies have been developed to allow students access into these texts, for example, the hermeneutic approach and so-called guided readings.

Considerations of original sources have raised theoretical questions about how mathematics ought to be taught in light of its history and philosophy. Because of this, but not only because of this, the past couple of decades have also seen an increase in critical and probing theoretical studies. This is, in our view, an extremely important phase in the way history and philosophy of mathematics have been taken up in educational research. For, 
while empirical research has been essential to see whether or not history of mathematics, say, has accomplished some pre-established educational ends, such as being productive for learning what we want to teach, it is equally important to understand what it means to learn history and philosophy of mathematics in the classroom: does it, for example, change our educational ends?

Some of these theoretical studies have appealed to already well-founded theoretical constructs, constructs from mathematics education research, general education, history and/or philosophy of mathematics as well as general history and philosophy. It is here that one finds in particular the ineluctable connections between educational studies of the history of mathematics and of philosophy of mathematics, mentioned above. In some cases, these studies have given rise to 'homegrown' frameworks specifically designed for the use of history of mathematics in mathematics education or for bringing out a particular philosophical position on mathematics (see Jankvist and Iversen in this issue).

In making our choices for papers in this issue, we tried to bring out this variety of ways researchers have come to think about problems and possibilities of incorporating history and philosophy of mathematics in mathematics education in recent years. This variety includes not only the different emphases we have just discussed, but also different directions of interest. We have thus included theoretically-oriented papers (e.g. Kjeldsen and Petersen; Barnett et al.); empirical papers (e.g. Panagiotou and Taani); papers concerning children (e.g. Cable), secondary students (e.g., Panagiotou; Papadopoulos), and teachers (Furinghetti et al.; Alpaslan et al.; Mosvold et al.; and Povey); and papers in the hybrid area of social issues in the history of mathematics education itself (Fiss). We should also say that in soliciting papers, we were not only interested in well-established figures in the fields, but also in younger and newer voices (e.g. Alpaslan and Taani), for as much as we wanted to provide a snapshot of present activity we also wanted to provide an intimation of work to be developed in the future.

\section{Four Sections}

The special issue is organized into four sections. In the first, authors discuss some theoretical issues in the use of the history of mathematics in teaching. Janet Barnett, Jerry Lodder and David Pengelley discuss their long-standing methodology of teaching university mathematics courses using original sources in the framework of various theoretical frameworks for the role of history. They present case studies of two of their guided student modules while also dealing with both the advantages and the challenges of using original sources. Tinne Hoff Kjeldsen and Pernille Hviid Petersen also use original sources, but this time in the context of a secondary school mathematics course dealing with functions and using the theoretical framework of a multiple perspective approach to history. They show how students' concept images often reflect those of some of the originators of the concept of function, rather than a more modern approach. Finally, Reidar Mosvold, Arne Jakobsen and Uffe Thomas Jankvist look at the theoretical framework of Mathematical Knowledge for Teaching to help show why elementary mathematics teachers can profit from studying the history of mathematics. In fact, the history of mathematics can contribute to both subject matter knowledge and pedagogical content knowledge, both of which are necessary parts of a prospective teacher's education.

The second section deals with the direct uses of the history of mathematics in the classroom. Ioannis Papadopoulos discusses his use of Archimedes' technique for computing $\pi$ in teaching sixth graders, while Evangelos Panagiotou taught secondary students 
some ideas of conic sections by using selected original sources from ancient and early modern times, while at the same time requiring students to reflect on the change from the original geometric description of a conic section to the more modern analytic one. Finally, Osama Taani describes how he uses material from al-Kashi's fifteenth century book, Key to Arithmetic, to demonstrate modern ideas of pedagogy to students in some elementary college courses.

In the third section, we look at how the history of mathematics is used in teacher education at various levels. Hilary Povey interviewed several mathematics teacher educators in the UK who have developed in their pre-service teachers an awareness of and an engagement in the history of mathematics. She reports on the various ways that this engagement has helped the teachers, including deepening their mathematical understanding and increasing their ability to think critically. Mustafa Alpaslan, Mine Isiksal and Cigdem Haser explore Turkish pre-service middle school teachers' knowledge of the history of mathematics, as well as their attitudes and beliefs toward using the history of mathematics in teaching. Finally, Fulvia Furinghetti, Giuseppina Fenaroli and Annamaria Somaglia use original sources dealing with the notion of derivative in their class of prospective secondary teachers to enable them to reflect on that concept and thus consider various ways of approaching it with their own pupils.

The final section of this issue deals with the relationship between the philosophy of mathematics and the teaching of mathematics as well as with an interesting aspect of the sociology of mathematics. Uffe Thomas Jankvist and Steffen Møllegaard Iversen look at why one should use philosophy in mathematics teaching and then how one could use it. Thus, philosophy, like history, can be used as a tool in teaching or as a goal toward which the teaching heads. The article also explores various ways of using philosophy in teaching. As a contrast, John Cable builds on the experiments that Jean Piaget performed on children to look at some important issues for mathematical philosophy, especially ideas surrounding the notion of "set". And finally, Andrew Fiss introduces the justification problem for mathematics teaching by exploring the nineteenth century rationales for teaching mathematics to women in the United States.

\section{A List of Selected 'Core Readings' in the Field}

Since, as initially mentioned, the topics of this special issue only occasionally find their way into Science \& Education, we offer a list of selected 'core readings' from the field, composed of books, handbook chapters, special issues in other journals, and often cited articles. It should be stressed that this list is our selection-other scholars might have chosen differently. Nevertheless, it is fairly comprehensive, containing both old and new 'classics'. It offers, in this way, a place for newcomers in the field to begin a survey of the literature. And of course, the reference lists of the selected books, chapters, and papers below point the readers to further 'core readings' in the field of history and philosophy in mathematics education.

Arcavi, A., Bruckheimer, M. \& Ben-Zvi, R. (1982). "Maybe a Mathematics Teacher can Profit from the Study of the History of Mathematics," For the Learning of Mathematics 3, 30-37.

Calinger, R. (ed.) (1996). Vita Mathematica: Historical Research and Integration with Teaching. Washington: Mathematical Association of America. 
Clark, K. M. (2013). History of Mathematics in Teacher Education, in Matthews, M. (ed.), International Handbook of Research in History, Philosophy and Science Teaching. New York: Springer.

Ernest, P. (ed.) (1994). Mathematics, Education and Philosophy: An International Perspective. London: The Falmer Press.

Fauvel, J. (1991). "Using History in Mathematics Education," For the Learning of Mathematics 11 (2), 3-6.

Fauvel, J. \& Maanen, J. van (eds.) (2000). History in Mathematics Education: The ICMI Study. Dordrecht: Kluwer Academic Publishers.

Francois, K. \& Van Bendegem, J. P. (eds.) (2010). Philosophical dimensions in mathematics education. New York: Springer.

Fried, M. N. (2001). "Can Mathematics Education and History of Mathematics Coexist?" Science and Education 10, 391-408.

Fried, M. N. (2013). History of Mathematics in Mathematics Education, in Matthews, M. (ed.), International Handbook of Research in History, Philosophy and Science Teaching. New York: Springer.

Furinghetti, F. (2000). "The history of mathematics as a coupling link between secondary and university teaching." International Journal of Mathematical Education in Science and Technology 31 (1), 43-51.

Furinghetti, F, Radford, L, \& Katz, V. (eds.) (2007). The History of Mathematics in Mathematics Education: Theory and Practice, special issue of Educational Studies in Mathematics 66 (2).

Furinghetti, F. \& Radford, L. (2002). Historical Conceptual Developments and the Teaching of Mathematics: From Philogenesis and Ontogenesis Theory to Classroom Practice, in English, L. (ed.), Handbook of International Research in Mathematics Education, Mahwah, NJ: Lawrence Erlbaum Associates.

Glas, E. (2013). A Role for Quasi-Empiricism in Mathematics Education, in Matthews, M. (ed.), International Handbook of Research in History, Philosophy and Science Teaching. New York: Springer.

Grabiner, J. V. (2013). The Role of Mathematics in Liberal Arts Education, in Matthews, M. (ed.), International Handbook of Research in History, Philosophy and Science Teaching. New York: Springer.

Gulikers, I. \& Blom, K. (2001). “'A Historical Angle,' a Survey of Recent Literature on the Use and Value of History in Geometrical Education," Educational Studies in Mathematics 47, 223-258.

Jankvist, U. T. (2009). “A Categorization of the 'whys' and 'hows' of Using History in Mathematics Education," Educational Studies in Mathematics 71, 235-261.

Jankvist, U. T. (2013). On the Use of Primary Sources in the Teaching and Learning of Mathematics, in Matthews, M. (ed.), International Handbook of Research in History, Philosophy and Science Teaching. New York: Springer.

Jardine, D. \& Shell-Gellasch, A. (eds.) (2011). Mathematical Time Capsules: Historical Modules for the Mathematics Classroom. Washington: Mathematical Association of America.

Katz, V. (1993). "Using the History of Calculus to Teach Calculus," Science \& Education 2, 243-249.

Katz, V. \& Michalowicz, K. (eds.) (2004). Historical Modules for the Teaching and Learning of Mathematics. Washington: Mathematical Association of America.

Katz, V. (ed.) (2000). Using History to Teach Mathematics: An International Perspective, Washington: Mathematical Association of America. 
Katz, V. \& Tzanakis, C. (eds.) (2011). Recent Developments on Introducing a Historical Dimension in Mathematics Education. Washington: Mathematical Association of America.

Kjeldsen, T. H. \& Blomhøj, M. (2012).”Beyond motivation: history as a method for learning meta-discursive rules in mathematics." Educational Studies in Mathematics, 80 (3), 327-349.

Kjeldsen, T. H. \& Carter, J. (2013). The Role of History and Philosophy in University Mathematics Education, in Matthews, M. (ed.), International Handbook of Research in History, Philosophy and Science Teaching. New York: Springer.

Knoebel, A., Laubenbacher, R., Lodder, J. \& Pengelley, D. (2007). Mathematical Masterpieces: Further Chronicles by the Explorers. New York: Springer.

Laubenbacher, R. \& Pengelley, D. (1999). Mathematical Expeditions: Chronicles by the Explorers. New York: Springer.

Rowlands, S. (2013). Philosophy and the Secondary School Mathematics Classroom, in Matthews, M. (ed.), International Handbook of Research in History, Philosophy and Science Teaching. New York: Springer.

Sfard, A. (1995). "The Development of Algebra: Confronting Historical and Psychological Perspectives," Journal of Mathematics Behavior 14, 15-39.

Shell-Gellasch, A. \& Jardine, D. (eds.) (2005). From Calculus to Computers: Using the Last 200 Years of Mathematics History in the Classroom. Washington: Mathematical Association of America.

Shell-Gellasch, A. (ed.) (2007). Hands on History: A Resource for Teaching Mathematics. Washington: Mathematical Association of America.

Sriraman, B. (ed.) (2012). Crossroads in the History of Mathematics and Mathematics Education. The Montana Mathematics Enthusiast Monographs 12. Charlotte: IAP.

Swetz, F, Fauvel, J, Bekken, O, Johansson, B., \& Katz, V. (eds.) (1996). Learn from the Masters! Washington: Mathematical Association of America.

Acknowledgments The editors wish to thank not only our authors for submitting articles but also the referees who have worked very hard to insure that articles are as clear and compelling as possible: Amy Ackerberg-Hastings, Janet Barnett, Janet Beery, Paolo Boero, George Booker, Robert Carson, Luis Casas, Renaud Chorlay, Kathleen Clark, Daniel Curtin, Thomas Drucker, John Earle, Fulvia Furinghetti, Bonnie Gold, Judy Grabiner, Ted Graham, David Guillemette, Gail Kaplan, Herbert Kasube, Tinne Hoff Kjeldsen, Gerard Landwarden, Snezana Lawrence, David Pengelley, Peter Ransom, Beverly Reed, Leo Rogers, Gert Schubring, Amy Shell-Gellasch, Man-Keung Siu, Bjørn Smestad, Steve Thornton, Constantinos Tzanakis, Iris van Gulik, and Marina Ville. 